\title{
Confession and Social Space in the DECAMERon
}

\section{Katherine A. Brown}

Abstract: This essay argues that confession in the Decameron is a liminal activity, which affords characters and readers a milieu removed from the space of society in which transformation and ultimately a temporary moment of transcendence of the secular world (almost a return to paradise) are achieved. In the tales of the Decameron in which confession is central to the narrative (novelle I.1, III.3, and VII.5), the liminal is a locus of trickery. Boccaccio subverts the notion of spiritual transcendence traditionally associated with the sacrament of confession and playfully substitutes the profane and the divine for each other. The parallels these stories establish between confession as a liminal activity and reading the Decameron suggests that Boccaccio's masterpiece has the potential to transform its public in social but not necessarily metaphysical ways.

Tales in the Decameron that relate a scene of would-be sacramental confession do so primarily in the service of comedic trickery. Confession is central to the plot in novelle I.1, III.3, and VII.5, where it is used for deception. ${ }^{1}$ The combination of ritual and entertainment in these tales is, to some degree, a critique of confession as an institution, or at least of the practices of confession in fourteenth-century Europe. In this regard, these confession stories add another facet to the Decameron's rich tradition of anticlerical satire because they reveal the ways in which this particular sacrament, based more on words than deeds, is

\footnotetext{
${ }^{1}$ These are the tales in which confession is central to the plot. All references to the Decameron refer to the edition by Vittore Branca with English translations by G. H. McWilliam. Other tales involve shorter confessions or allusions to confessions, for example III.8, in which Ferondo's wife makes a confession to the Abbot who uses the opportunity to propose both a secret liaison and a way to cure Ferondo of his jealousy. One exception to the connection between comedy and confession is the eighth tale of Day II, where the Queen's confession is the dénouement of the narrative. Though the tone of the tale is more tragic than comic, the Queen's confession undoes her previous deception and exonerates the Count, thereby giving the novella an uplifting ending, one more in line with the Dantean sense of comedy. I would like to thank the anonymous reviewer for pointing out this exception.
} 
subject to falsehoods and manipulation. ${ }^{2}$ Indeed, the narratives about confession in the Decameron underscore language's ability to transform the individual and society, but the resulting transcendence is primarily physical and not spiritual, and temporary rather than enduring, in these stories. Though the Decameron as a whole may reveal narrative's potential to alleviate suffering, such as that of the donne amorose in the Proemio or that which is caused by the Plague among the brigata $^{3}$ the stories of confession in particular deal with overcoming obstacles by forging a new space for relief and reward. The language in these tales creates an ambiguous, in-between space, ${ }^{4}$ where the sacred meets the profane, where the literal blends with the figurative, where the line separating exclusion from inclusion is constantly being moved and blurred-in short, it is a space that allows the tricksters to sidestep social (and even physical) impediments in order to attain their worldly goals.

Confession lends itself particularly well to linguistic ambiguity and tricks (beffe) because it is intended as a transformative act that is both of the spirit but also necessarily of the body, private and also public, transcendent and still mundane. During confession, social identity is suppressed in favour of the Christian identity of the sinner. The sacrament is meant to forgive the penitent's sins and restore grace to the soul. It allows for communion with the Church and with God, who alone can forgive the penitent, though the absolution is perfected by the priest. The elevation resulting from confession is, in the community of Christians, an elevation of the soul. Confession is a practice associated with a privileged space; even if not in a proper confessional in most Decameron tales or in

\footnotetext{
2 The other sacraments are more immediately connected to the physical, usually with the individual as the recipient of prescribed actions: water and oil are poured on the individual at baptism; the Eucharist is taken orally; oil is applied to the individual for confirmation and anointing of the sick; a marriage is consummated physically in most cases; and holy orders require the individual to practise and/or witness the other sacraments. On penance in the High Middle Ages, see Thomas Aquinas, Summa theologica, III, q. 84, art. 1. See also Biller and Minnis; Payer, esp. 45-74; McNeill and Gamer; and École française de Rome. For studies on religion and anticlericalism in the Decameron, see Ó Cuilleanáin, esp. 148-176; and Havely. See also the notes below to individual stories for their treatment of religion, anticlericalism, and antifraternalism.

3 This view of Boccaccio's poetics, and the Decameron in particular, to offer succour or rather to "cure" its audience is espoused by many, notably Gittes. See also his essay in this volume.

${ }^{4}$ The concept of being "in-between" discussed in this essay is informed by Turner's work on the liminal phase in rites of passage (The Forest of Symbols and From Ritual to Theatre).
} 
fourteenth-century Europe generally, ${ }^{5}$ it is still clearly set apart from other social activities. The space is functionally in between the secular world and the spiritual world. Confession is also characterized by specific language, from the absolute honesty required of the penitent to the particular formula of absolution, ego te absolvo, pronounced by the confessor. To be sure, the confessor's role is highly regulated and codified at this time; his function is in large part performative. ${ }^{6}$ As penance both serves the common good of Christianity in all times and all places and is an outward sign of inner grace, it offers secondary benefits to the individual in secular society. ${ }^{7}$ Confession establishes a space where, through language, grace and even order may be restored to the individual. In this respect, the narratives centred on confession parallel the brigata's 10 days of storytelling, as if to suggest that confessions, like stories, are narratives of our actions that we tell to improve ourselves. The social function of confession, then, which relieves the penitent of feelings of guilt and restores order, is the only effective result of this sacrament, since the transcendental benefits can only be measured in the afterlife. This view is upheld in the first story of the Decameron, which illustrates the problem, if not the impossibility, of affirming knowledge of divine will in earthly terms.

\section{Ambiguity in $\mathrm{I} .1$}

Novella I.1 relates the false confession of Ser Cepparello. The focus on space throughout the story is intimately tied to the use of deceptive language. For all of the geographical specificity at the beginning of the tale, the references to locations announce the uncertainty of the confessional space that dominates the narrative, which, in turn, is linked to the ambiguity of the social status of several characters and of language itself:

Ragionasi adunque che essendo Musciatto Franzesi di ricchissimo e gran mercatante in Francia cavalier divenuto e dovendone in Toscana

\footnotetext{
${ }^{5}$ In addition to the studies of penance in the Middle Ages cited in note 2, see Ó Cuilleanáin (149), who explains that confession would have been face-to-face in Boccaccio's time and therefore less private than it would later become during the Reformation.

${ }^{6}$ Manuals of confessors were quite detailed and followed a strict order, as Susanna Barsella and Simone Marchesi show in their essays in this volume.

${ }^{7}$ In this way, confession corresponds with Turner's explanation that the authority of the liminal phase is absolute because it reflects "the axiomatic values of society" (The Forest of Symbols 100).
} 
venire con messer Carlo Senzaterra, fratello del re di Francia, da papa Bonifazio addomandato e al venir promosso, sentendo egli li fatti suoi, sí come le piú volte son quegli de' mercatanti, molto intralciati in qua e in là e non potersi di leggiere né subitamente stralciare, pensò quegli commettere a piú persone e a tutti trovò modo: fuor solamente in dubbio gli rimase cui lasciar potesse sofficiente a riscuoter suoi crediti fatti a piú borgognoni. E la cagione del dubbio era il sentire li borgognoni uomini riottosi e di mala condizione e misleali; e a lui non andava per la memoria chi tanto malvagio uom fosse, in cui egli potesse alcuna fidanza avere, che opporre alla loro malvagità si potesse. E sopra questa essaminazione pensando lungamente stato, gli venne a memoria un ser Cepparello da Prato, il quale molto alla sua casa in Parigi si riparava; il quale, per ciò che piccolo di persona era e molto assettatuzzo, non sappiendo li franceschi che si volesse dir Cepparello, credendo che 'cappello', cioè 'ghirlanda' secondo il lor volgare a dir venisse, per ciò che piccolo era come dicemmo, non Ciappello, ma Ciappelletto il chiamavano: e per Ciappelletto era conosciuto per tutto, là dove pochi per ser Cepperello il conoscieno. (I.1.7-9; emphasis added)

It is said, then, that Musciatto Franzesi, having become a fine gentleman after acquiring enormous wealth and fame as a merchant in France, was obliged to come to Tuscany with the brother of the French king, the Lord Charles Lackland, who had been urged and encouraged by Pope Boniface. But finding that his affairs, as is usually the case with merchants, were entangled here, there, and everywhere, and being unable to quickly or easily unravel them, he decided to place them in the hands of a number of different people. All this he succeeded in arranging, except that he was left with the problem of finding someone capable of recovering certain loans which he had made to various people in Burgundy. The reason for his dilemma was that he had been told the Burgundians were a quarrelsome, thoroughly bad and unprincipled set of people; and he was quite unable to think of anyone he could trust, who was at the same time sufficiently villainous to match the villainy of the Burgundians. After devoting much thought to this problem, he suddenly recalled a man 
known as Ser Cepperello, of Prato, who had been a frequent visitor to his house in Paris. This man was short in stature and used to dress very neatly, and the French, who did not know the meaning of the word Cepperello, thinking that it signified "chapel," which in their language means 'garland', and because as we have said he was a little man, used to call him, not Ciappello, but Ciappelletto: and everywhere in that part of the world, where few people knew him as Ser Cepperello, he was known as Ciappelletto. (25; emphasis added)

The proliferation of place-names and demonyms in these introductory sentences grounds the text in a real setting, one that would be familiar to Boccaccio's audience. Nevertheless, the presentation of these places also goes back and forth, imitating the complex business and personal entanglements of Musciatto Franzesi. Indeed, the passage makes it hard to pin down Musciatto and his affairs, even within this restricted geography. That Musciatto and his business dealings are not firmly fixed is reflected in the equivocal nature of most of the characters and is as much linguistic as it is spatial. Musciatto Franzesi, whose surname is an Italian translation for "the French," is a knight in France, has business affairs in France, and will soon attend to the brother of the King of France. Yet his ties to France are ending as he is going to Tuscany with the support of the Italian Pope Boniface, but first he needs to recover his money from the Burgundians with the help of a Tuscan named Ser Cepparello, whom he knows from Paris. Musciatto's FrancoItalian connections establish him as a figure between two countries, or rather two regions, and two languages. In short, Musciatto, and every character connected with him in the tale, is in transition, both physically and socially, for not only has he recently been made a knight, but his new position with the brother of the king suggests a socio-political elevation as well. Placed neither in France or Italy, nor decidedly from France or Italy, he cannot be fixed spatially in the tale because he is in a process of change.

Musciatto's ambiguous place in the world shows the correspondence between space and social position, which is also evident in another man of indeterminate place: Charles Senzaterra (Without Land/Lackland), for whom Musciatto will work. Charles's impotent social station as not-the-French-monarch, who is being invited abroad to Italy, reinforces the connection between place and social 
situation. ${ }^{8}$ The lack of a clearly defined place of origin or definitive spatial affiliation for Musciatto and his associates establishes a relationship between transitional space, social ambiguity, and language that will come to dominate the tale.

Similarly, his old affairs in France are not finished, and he has not yet begun his new position; Musciatto's business affairs are "intralciati in qua e in lä" and he needs to stralciare the impediments in order to proceed. The status of his affairs lies on the threshold between tied up and untied in an ambiguous state of movement between the two: the untying motion that is neither altogether constrained nor clearly free. Thus, movement in this passage alludes to a temporary phase, a transition in every sense that is neither here nor there.

The repetition of verbs of movement reinforces this connection between social flux and spatial indeterminacy: specifically venire (including divenuto) is used five times in the passage and is opposed to a single use of andare such that coming and going are necessary opposites in the process of becoming. The use of the verb potere four times suggests the potential of this ambiguous state, the still unrealized desire and capacity to move forward. In spite of the ebb and flow of the passage, every aspect of Musciatto's life points to his seeming to be stuck "betwixt and between" two states and that, in order to progress, he must seek the help of another.

Musciatto's indeterminacy announces the nebulousness of the man he hires to recover his money in Burgundy, Ser Cepparello, also spelled Cepperello in Branca's edition. ${ }^{10}$ Even the orthographic instability of his name signals that he,

\footnotetext{
${ }^{8}$ John Lackland, on whom the name Charles Senzaterra is most likely based, did in fact become King of England after the death of his brother Richard I (the Lionheart), but his reign was marked by the loss of Angevin territory on the continent. The relationship between sociopolitical power and land evoked in the tale seems to be confirmed by this historical allusion. The reference to the Pope, presumably Boniface VIII whom Dante famously placed in the eighth circle of hell, evokes his invitation to Philip's brother Charles of Valois to invade the Italian peninsula, as well as his long-standing feud with King Philip IV of France, which pitted the spiritual jurisdiction of the papacy against the secular domain of the kingdom of France. On the historical significance of this tale, see also Getto 40-43.

${ }^{9}$ See Turner, The Forest of Symbols, esp. 62.

${ }^{10}$ Although medieval orthography was less consistent than modern standards demand, in most modern editions of the Decameron, the spelling of characters' names seems relatively stable. For this reason, I suggest that the ambiguity of the spelling Cepparello/Cepperello is not just a modern editorial choice but perhaps a reflection of Boccaccio's intention to make this character hard to pin down in every way. On this name, see also D'Agostino 127-128.
} 
too, is not fixed, for his sign, his very identity, remains unstable. Ser Cepparello does not seem connected to a specific place, for he is introduced as being from Prato, but later in the tale he is referred to as a Lombard (I.1.30), though his business is primarily in France. The linguistic slipperiness that the transition between France and Italy suggests for both men comes to fruition in Ser Cepparello, who is given two different names to correspond with the two countries in which he operates. Moreover, his name in France, "Ser Ciappelletto," is based on a misunderstanding of his Italian name and the addition of a diminutive ending-his name has thus been transformed semantically in two ways, just as his identity will be altered and stabilized after his false confession. ${ }^{11}$ In this way, place is also linked with linguistic instability in the person of Ser Cepparello. Moreover, the two brothers, who are associates of Musciatto and house Cepparello during his final days, are displaced Lombards living in Burgundy. Their reputation in France ultimately hinges on Cepparello's words. From the outset, Musciatto Franzesi and his associates, especially Ser Cepparello, enjoy the transitional vagueness of liminal figures, floating on the edges of society.

The entire tale seems to be set up in a transitory state, one that recalls the plague-ridden city of Florence in which "era la reverenda auttorità delle leggi, cosí divine come umane, quasi caduta e dissoluta tutta" (I.Intro.23; "all respect for the laws of God and man had virtually broken down and been extinguished," 7-8). The old way of life no longer being possible, order has not yet been restored to implement a new way of life in Florence, therefore society is itself between two phases. It is this instability of Florentine society that compels the brigata to remove itself to the country for a short time. As with the brigata in the gardens of the countryside, the geographical movement described in novella I.1 will come to a temporary focus on the room where Ser Ciappelletto gives his confession.

Following the introduction filled with deliberate spatial meanderings is the description of Cepparello as "il piggiore uomo forse che mai nascesse" (I.1.15; "perhaps the worst man that was ever born" 26), which begins with his many sins. The emphasis on false documents and false witness as the first of Cepparello's sins implicates the ambiguity of language and the impossibility of being able to fix language in much the same way that the men in the tale cannot be fixed geographically or socially. Moreover, the impossibility of locating and stabilizing

\footnotetext{
${ }^{11}$ For an introduction to the name change of Cepparello to Ciappelletto as related to his deception, see Marcus; Almansi, esp. 24-55; and Getto 43-53. For a detailed bibliography on novella I.1, see the articles by Barsella and by Marchesi in this volume.
} 
characters and their language evokes the transcendental problem of the tale, which is the impossibility of knowing on whom God bestows his grace, of knowing who is a saint and who is not.

Of course, Ciappelletto's confession is the ultimate verbal sin, and as scholars have pointed out, its order is a systematic reversal of the sins the narrator enumerates when Ciappelletto is introduced. ${ }^{12}$ This reversal of the narrative text-not the actions of the story - constitutes a re-ordering of Ciappelletto's sins that equates Panfilo's storytelling with Ciappelletto's own invention. The suggestion is that Ciappelletto's re-creation of reality during confession is no more and no less an act of diversion than Panfilo's storytelling. But Ciappelletto's story is understood very differently by his two audiences: the Lombard brothers of Burgundy can hardly keep from laughing at his lies during his confession, whereas the holy friar believes his words and his actions to be outward signs of inner grace.

These diverse reactions are more than just a reflection of the expectations of each audience because Ciappelletto's responses to the friar's questions are often ambiguous. Indeed, he starts his confession with a seemingly ambiguous, but ultimately truthful, statement:

' $[\mathrm{I}]$ o non mi confessai mai tante volte né sí spesso, che io sempre non mi volessi confessare generalmente di tutti i miei peccati che io $\mathrm{mi}$ ricordassi dal dí che io nacqui infino a quello che confessato mi sono; e per ciò vi priego, padre mio buono, che cosí puntalmente d'ogni cosa mi domandiate come se mai confessato non mi fossi.' (I.1.34; emphasis added)

'(H)owever frequently or regularly I confess, it is always my wish that I should make a general confession of all sins I can remember committing from the day I was born till the day of my confession. I therefore beg you, good father, to question me about everything, just as closely as if I had never been confessed.' (29)

In fact, the narrator informs his audience that this is Ciappelletto's first confession. In addition to this pronouncement, parts of many of his answers are also true.

\footnotetext{
12 On the relationship between Panfilo's description of sins and Cepparello's confession, see Almansi 30 and 46-51; Getto 43-69; the notes in D'Agostino 39-48, 130-135, and 146-147; and Usher.
} 
For example, in discussing gluttony, the first part of his answer is true if Panfilo's initial portrait of Ciappelletto is to be believed: "E appresso questo il domandò se nel peccato della gola aveva a Dio dispiaciuto. Al quale, sospirando forte, ser Ciappelletto rispose di si e molte volte" (I.1.41; "Next he asked him whether he had displeased God by committing the sin of gluttony; to which, fetching a deep sigh, Ser Ciappelletto replied that he had, and on many occasions," 30; emphasis added). He answers truthfully in the affirmative for the sins of anger, bearing false witness, and cheating others as well, even though the specific incidents of sin that he mentions are false, as are many other of his responses. His answer that he has not sinned carnally with a woman is true to the letter of the law because he is instead guilty of sodomy. But the uncertainty and misleading nature of his responses, rather, makes his confession all the more ambiguous. The interspersion in his confession of not only truthful utterances but also Christian truths and axiomatic values marks the convergence of the sacred with the profanity of the trickster. The rhetoric of the trickster is intertwined with that of the holy man just as it is the same for Ser Cepparello, possibly the worst man who ever lived, and for saint Ciappelletto, to whose name miracles are later attributed in Burgundy.

It is also through language that Ser Ciappelletto's renown as a holy man of God is made, for the friar who confessed him first tells the chapter at the monastery about the holiness he witnessed and subsequently informs the community of believers in a homily:

e in brieve con le sue parole, alle quali era dalla gente della contrada data intera fede, sí il mise nel capo e nella divozion di tutti coloro che v'erano. (I.1.86)

and in brief, with a torrent of words that the people of the town believed implicitly, he fixed Ser Ciappelletto [very] firmly in the minds and affections of all those present. (36)

The irony of the sinner being venerated as a saint is matched by the irony that language is an adequate means to convey divine will and the bestowal of grace. While Ser Ciappelletto's comments on holy practice never presume to know the will of God, only the law which man has to follow, the friar's language seems rather to betray a greater sense of certainty: 
'[S]e tu fossi stato un di quegli che il posero in croce, avendo la contrizione che io ti veggio, sí ti perdonerebbe Egli.' (I.1.72)

'[E]ven if you had been one of those who set Him on the cross, I can see that you have so much contrition that He would certainly forgive you.' (34)

' $[\mathrm{M}] \mathrm{a}$ se pure avvenisse che Idio la vostra benedetta e ben disposta anima chiamasse a sé.' (I.1.75)

'[B] ut in case it were to happen that God should summon your blessed and well-disposed soul to His presence.' (34)

In this way, the confessional space in this tale is practically a complete reversal of social norms, for the sinner nearly instructs the confessor in holiness, ironically using more appropriate rhetoric.

In terms of narrative space, Ciappelletto's confession takes up nearly half of the tale, during which it condenses the (fake) life of Ciappelletto into the space of a single confession. A lifetime, like a confession, may be ordered and condensed into a narrative, an interlude. In a spiritual sense, earthly life is a limited preparation for eternal life, a time when actions transform the soul, for better or worse, and from which the Christian transitions to paradise, purgatory, or hell. ${ }^{13}$ In this respect, life on earth may be considered a liminal phase in the life of the soul. Thus, it is not really possible to assign a spiritual status to Ser Cepparello as saved or damned, in spite of the holy friar's efforts to cement Ciappelletto's example among the Burgundian people. Panfilo clearly explains this impossibility at the

${ }^{13}$ As Augustine says in De Doctrina Christiana:

sic in huius mortalitatis vita peregrinantes a Domino, si redire in patriam uolumus ubi beati esse possimus, utendum est hoc mundo, non fruendum, ut inuisibilia Dei per ea quae facta sunt intellecta conspiciantur, hoc est, ut de corporalibus temporalibusque rebus aeterna et spiritalia capiamus" (I.IV.4; original emphasis)

So in this mortal life we are like travellers away from our Lord: if we wish to return to the homeland where we can be happy we must use this world, not enjoy it, in order to discern the invisible attributes of God, which are understood through what has been made' or, in other words, to ascertain what is eternal and spiritual from corporeal and temporal things. (Green). 
end of the tale (I.1.89); indeed, this novella underscores that our understanding of temporal existence ends on earth and one cannot know that which is beyond its limits. Any order applied to terrestrial events is necessarily a fabrication of man. The spiritual transformation, if any, afforded by the transitional time on earth cannot really be measured in earthly terms, but time on earth can mark earthly changes and, in particular, social changes. Thus, there is no absolute point of reference in language, in society, or in the church. Language can create liminality just as it can be subject to the liminal, as the following tale on confession validates.

\section{Social standing in III.3}

Filomena narrates the third tale of the Third Day in which a woman uses her confessions to a friar as a means to alert a gentleman she admires to her amorous desires. The most overtly anticlerical of the tales centred on confession in the Decameron, novella III.3 also reveals a preoccupation with social status that surpasses that of the other tales about confession. Although the purpose of confession is not, strictly speaking, to enhance social standing in terrestrial terms, but rather to enact an elevation of the soul, Boccaccio's manipulation of the sacrament in this tale reveals additional limitations of man as it furthers the message that the social relevance of confession is the best that can be gleaned from this practice. Filomena introduces her tale with an anticlerical diatribe focusing on the lack of intelligence among the clergy:

[I religiosi] si credono piú che gli altri in ogni cosa valere e sapere, dove essi di gran lunga sono da molto meno" (III.3.3)

[The religious] consider themselves in all respects more worthy and knowledgeable than other people, whereas they are decidedly inferior (205)

This characterization of the clergy links intelligence with worth and social standing - a connection that the tale forges against the clergy and in favour of the nobility. Indeed, the married lady in the novella justifies her desire for another man - a gentleman — by lamenting the social inequality between herself and her husband: 
Costei adunque, d'alto legnaggio veggendosi nata e maritata a uno artefice lanaiuolo, per ciò che artefice era non potendo lo sdegno dell'animo porre in terra, per lo quale stimava niuno uomo di bassa condizione, quantunque ricchissimo fosse, esser di gentil donna degno. (III.3.6)

This lady, being of gentle birth and finding herself married off to a woollen-draper (and) because he (was just an artisan), was unable to stifle her heartfelt contempt, for she was firmly of the opinion that no man of low condition, however wealthy, was deserving of a noble wife (206 translation modified).

The indirect discourse that gives insight into the lady's rationale moves from her specific case to a generalization about any man of low condition being married to any noble lady, making it a social question. This reasoning suggests that (carnal) love ought to exist only among equals and that social status, which is set by birth, determines one's worthiness for love. Indeed, this account of love differs little from the dictates of courtly love as explained by Andreas Capellanus, ${ }^{14}$ even though it is at odds with other tales of love in the Decameron.

Later in the novella, the lady's trick, which consists of telling the friar in confession what she wishes were true in order to produce it, also connects social milieu with the capacity to understand a certain type of discourse. The friar's failure to understand the true meaning of the lady's complaints against the gentleman-to understand these complaints as anything other than absolute truths and as inviting the gentleman's advances— sets the friar apart on an intellectual level. That the

\footnotetext{
${ }^{14} \mathrm{I}$ am not ascribing these sentiments to Boccaccio, for love in the Decameron is quite complex, but the position of the noblewoman in novella III.3 certainly conforms to the dictates of Andreas Capellanus's work. See, for example, Andreas's comments on which people may love; De Amore, Book I, ch. 2 and 5; and the many troubled dialogues between high- and low-born women and men in Book I, ch. 6. The situation in the second dialogue of chapter 6 is reminiscent of the marriage in novella III.3, for the man of the middle class (plebeius) is unable to convince the woman of the nobility to give him her love and she spurns him with an argument based on class distinctions: "Si enim, prout asseris, sola morum probitas amoris invenitur digna muneribus et nobilem facit hominem reputari, superfluo antiquitus nobilitatis fuit ordo repertus" (Battaglia 58; "If, as you say, we find good character alone worthy of Love's rewards and that this makes people look upon a man as noble, then the order of nobility [...] would long ago have been found to be useless," Parry 51).
} 
two noble-born characters share an understanding of the intention behind her language reinforces the affinity between social status and intelligence; unlike the friar, they have been indoctrinated into the secular notion of carnal love. Thus in novella III.3, the characters who are already acquainted with eros understand the discourse associated with it, whereas the clergy as a category, and this friar as a specific case, are necessarily excluded from it. The irony here, as will also be seen in novella VII.5, is that sexuality is normally suspended and atoned for during a confession, but these women-tricksters use this privileged space to promote their amorous dalliances. ${ }^{15}$ The specialized discourse of love among nobles is initiated during confession, which corresponds to a discrete place and time, removed from the rest of society. To be sure, the lady in novella III.3 is wary of making her feelings known in any other way: "e ella, che molto cauta era, né per ambasciata di femina né per lettera ardiva di fargliele sentire, temendo de' pericoli possibili a avvenire" (III.3.7; "and for her part, being very cautious, she would not venture to declare her love by dispatching a maidservant or writing him a letter, for fear of dangers that this might entail," 206). The lady has only the space of confession at her disposal, and yet her orchestrations depend on the friar's inability to keep this space discrete from, and her words discreet before, the gentleman.

In the story she fabricates for the friar about the gentleman's unwanted attention, the lady mentions enclosed space as one of the consequences, and limits, of the man's attention: “' $[\mathrm{N}]$ é posso farmi né a uscio né a finestra, né uscir di casa, che egli incontanente non mi si pari innanzi”" (III.3.11; "he turns up infallibly whenever I either look out of a window or stand at the front door or leave the house'," 207). It is significant that the lady speaks about thresholds between her house and the outside world where she sees the man because they cannot be together in the open. Her trick, like her would-be liaison, requires a location removed from society. Thus, novella III.3, like Cepparello's confession, connects confession (the sacred) and deception (the profane) because both must be removed in space, away from society generally and out of the friar's sight more specifically, to be successful, and both activities are united in the language the lady uses in the

\footnotetext{
${ }^{15}$ Indeed, the woman in novella VII.5 even makes a point of the impropriety of revealing her speech to her husband: "il geloso [...] domandò la moglie ciò che ella avesse al prete detto la mattina che confessata s'era. La donna rispose che non gliele voleva dire, per ciò che ella non era onesta cosa né convenevole" (VII.5.46; "the jealous husband [...] demanded to know what his wife had said to the priest on the morning she had gone to confession. She told him that his question was neither fair nor proper, and refused to answer it," 511-512).
} 
confessional. ${ }^{16}$ The confessional space and the lady's language are the thresholds of meaning through which the gentleman must pass in order to enjoy the lady's company. In mercantile terms, language is once again the medium of transaction for those who agree on its value.

The lady's standing in society would be ruined were this news made public, as she herself states: "acciò che male e scandalo non ne nascesse, me ne son taciuta" (III.3.12; "so in order to avoid unpleasantness and scandal, I have always held my tongue," 208). The lady's talk of her reputation, which she guards scrupulously, is not just rhetoric to please the friar-it is true. Her desire for silence, which serves to protect her from the judgment of society, stands in contrast to the friar's focus on appearances. Because the space created by confession masks the couple's desired rendezvous, the lady's reputation and social standing remain intact-in effect, the physical, intimate space of the couple will take the place of the confessional space created by language. The couple may reap the benefits of this exchange whereas society at large and the friar will have no knowledge of it.

Although the historical shift from public to private confession made the space of confession more intimate, it could still be done in plain view of others after the Fourth Lateran Council in 1215. The focus for the confessor, according to Canon law (Canon 21), relates more to the secrecy of the confession and of the penitent's speech, but the friar in this novella clearly violates this secrecy as he betrays his concern for the visual. The lady's trick, on the other hand, depends more on sight and the couple's ultimate separation from the prying eyes of society. The play of these senses in III.3 - as will also be shown in the case of VII.5-privileges words and hearing over sight. In both tales, confessional speech, which is eventually repeated to the lovers, occurs away from the view of society. More weight is given to seeing than hearing or speaking of a transgression, in some respects counteracting the primacy of speech in confession.

The words of the lady's confession are true in the sense that they re-order reality; her distorted presentation of her would-be suitor to the friar essentially reverses the order in which events occur. She tells him what the gentleman will do, but presents these incidents as having already taken place, thereby shaping

\footnotetext{
${ }^{16}$ Were the space open, the characters, or in Turner's terminology, the liminal figures, would be compromised, "polluted," and thus they would undermine the ritual. On pollution, see Turner (The Forest of Symbols) and his references to Mary Douglas (97).
} 
reality. ${ }^{17}$ Once the gentleman completes the actions she has set out for him (passing by her house daily, sending her gifts, climbing a tree to enter her house), the lady's speech is effectively validated, even though her shows of emotion to the friar remain deceptive. Only the friar remains ignorant of this re-organization of secular time and actions, for he places more stock in appearances.

The friar's language reveals his excessive concern with the appearance of treachery when he upbraids the gentleman, calling him a "malvagio uomo" (III.3.35) and "esso disse la maggior villania che mai ad uomo fosse detta, disleale e spergiuro e traditor chiamandolo" (III.3.47; [the friar] "gave him the fiercest scolding anyone ever had, calling him a disloyal traitor and a perjurer," 214).$^{18}$ In reprimanding his friend, the friar's language does not fail to evoke the depths of hell (the realm of traitors), and also the Jews who were considered guilty of crucifying Christ. The gentleman even asks him: "Perché questo cruccio, messere? ho io crocifisso Cristo?"” (III.3.47; "'Why are you creating such a fuss? Anyone would think I had crucified Christ'," 214). Rather than uplifting the community of Christians, the friar's language hypocritically judges and condemns.

Repeating the lady's tale to the gentleman constitutes the friar's breach of the confessional space and of Canon law. Once he is privy to part of the lady's confession, the gentleman becomes corrupted so to speak, for his own reputation before the holy friar, if not society at large, is at risk. While irony abounds in the tale-from the gentleman who clears his name with the friar by agreeing to meet the lady at her house, to the lady who offers a false accusation in the confessional, and finally to the friar who unwittingly permits the lady and his friend to commit adultery by revealing her confessional secrets—it nonetheless permits the maintenance, or rather return, of the status quo. The reputable appearances of the lady, the gentleman, and the holy friar undergo no transformation in the view of

\footnotetext{
${ }^{17}$ Fontes discusses the reordering of time (future and past) as an aspect of certain beffe in the Decameron, esp. 13. Not only is this reversal of complaint and action another reflection of liminality, but at the end of her second visit to the friar the lady tells him that her dreams are troubled by the ghosts of her relatives (III.3.31-32). For Turner, rituals of affliction, particularly afflictions of disquieted shades, constitute an important category of rituals, at least among the Ndembu, 1967, 9-11. In light of this, it appears that the lady's confessions are supercharged rites, as if to justify her repeated visits to the friar.

${ }^{18}$ Boccaccio uses similar phrasing, "dirle la maggior villania che mai a femina fosse detta" (IX.2.13) in a later tale that highlights hypocrisy among female religious. In both cases the phrase suggests the non-spiritual or worldly focus of these characters. The superlative is also reminiscent of the description of Cepparello in I.1.
} 
society. The confession, like the trick, remains separate from others. The trick, however, continues for the couple away from the friar and his confessional space. In this way, the lady and the gentleman, who trade the space of confession for the space of the lady's private bedroom when her husband is away, are always ready to re-enter this temporary, liminal space together, having managed to exclude the friar. Similarly, they no longer need to employ a special discourse that is unintelligible to the friar:

E dato ordine a' lor fatti, sí fecero, che senza aver piú a tornare a messer lo frate, molte altre notti con pari letizia insieme si ritrovarono: alle quali io priego Idio per la sua santa misericordia che tosto conduca me e tutte l'anime cristiane che voglia n'hanno. (III.3.55)

[After this first encounter, having devoted some little thought to the subject, they arranged matters in such a way that, without having further recourse to their friend the friar, they slept together no less pleasurably on many later occasions. And I pray to God that in the bountifulness of His mercy He may very soon conduct me, along with all other like-minded Christian souls, to a similar fate, 215.]

The language of their new space remains unknown to the friar and the audience alike, for it has been transformed into action. The final prayer supports the paradisiacal quality of the new erotic space, which offsets the infernal allusions that preoccupied the friar. Indeed, the lack of clerical mediation, the privacy and immediacy of their new language, and the joy they experience all suggest that this new space is akin to a temporary return to paradise. Moreover, Filomena's final prayer suggests that the lady's trick and its favourable results may be extended to another society, the one organized by the brigata in their own perfected space: the beautiful garden likened to an earthly Paradise (III.Intro.11) that is removed from their previous locations and serves as the new setting for Day Three through Day Six. If, as Tobias Foster Gittes has suggested elsewhere, Boccaccio asserts the possibility of a terrestrial paradise, novella III.3 links this exclusively to sexual encounters that are necessarily of limited duration. ${ }^{19}$ As for the role of

\footnotetext{
${ }^{19}$ Gittes: "For Boccaccio, the earthly paradise is in part a place, in part a philosophical attitude, and the recuperation of a personal state of beatitude (Adamic innocence) or of a collective state of beatitude (the Golden Age) is not simply the stuff of vain poetic imaginings but an empirically feasible and morally commendable aspiration" (29).
} 
confession, the lady's trick and the friar's violations show the sacrament's spiritual limitations while underscoring its potential social utility, even if perverted here. Understanding among people of different aims, and in this case social standing, is seemingly limited. Although language has the capacity to create social connections and liaisons, it may only do so for those who can decode it properly. Similarly, it can lead to a terrestrial paradise in the most physical sense, one that is inevitably ephemeral but repeatable. Indeed, this story suggests that paradise on earth must actively be sought after and sculpted, a marriage of word and deed.

\section{Transformation in VII.5}

Creating an earthly paradise in novella VII.5 requires two spaces that are set apart from the prying eyes of society. The first is the lady's house, where she is carefully guarded by her jealous husband:

E cosí ingelosito tanta guardia ne prendeva e sí stretta la tenea, che forse assai son di quegli che a capital pena son dannati, che non sono da' pregionieri con tanta guardia servati. (VII.5.8-9)

And in his jealousy he kept such constant watch upon her and guarded her so closely, that I doubt whether many of those condemned to death are guarded by their gaolers with the same degree of vigilance. (506)

Ironically, the husband's preoccupation with enclosing his wife facilitates her trick, for the prison-like home, which is removed from the very view of society, later becomes the locus of the lady's concealed and discreet adultery. Indeed, when the husband leaves the space of the wife's confinement, he provides the necessary opportunity for her neighbour to enter her room. In this way, the lady's chamber joins the limits of confined space with the deception of the wife, all while excluding her husband.

The second enclosed space is the church where the husband, disguised as a priest, hears his wife's confession. In the sacred space of VII.5, the husband attempts to efface his identity in order to trick his wife: "Il geloso [...] messasi prestamente una delle robe del prete con un cappuccio grande a gote come noi veggiamo che i preti portano, avendosel tirato un poco innanzi, si mise a sedere in 
coro" (VII.5.20; "he disguised himself in the robes of a priest, with a large hood that came down over his cheeks, like the ones that are often worn by priests; this he pulled forward a little, so as to conceal his features, then he seated himself in one of the pews [of the choir]," 508).

By adopting a costume that not only hides his face but also symbolically signifies removal from secular society, the husband places himself at the crossroads of domestic and public life, of the secular and clerical domains. His initial seat in the choir reinforces the in-betweenness of his position, for the choir in medieval churches was usually situated between the altar and the nave, the space between the sacred and the profane, so to speak. In spite of his physical alteration, the wife recognizes her husband when he approaches her and is able to trick him with her confession..$^{20}$ Though the ambiguity of the husband's appearance is an attempted trick, it fails. Conversely, the ambiguous language of the wife's confession succeeds in duping her husband. Language creates opportunities for new understandings of the world, even false ones, whereas visual illusions are the currency of fools. The wife's narrative about her adulterous affair with a priest seems to intimidate her husband by alluding to the priest's "arte" and the use of "certe parole" that allow all locked doors to open before him as if they were magical manifestations (VII.5.28). Conflating the sacred and the magical, the spiritual and the carnal, her words are a veiled account, in marvellous detail, of her ordinary routine with her husband, but one that points to the power of language, certe parole, to perform marvellous deeds.

As the lady herself explains at the end of the narrative, her confession is not false precisely because it applies to her husband:

'Io ti dissi che io amava un prete: e non eri tu, il quale io a gran torto amo, fatto prete? Dissiti che niuno uscio della mia casa gli si potea tener serrato quando meco giacer volea: e quale uscio ti fu mai in casa tua tenuto, quando tu colà dove io fossi se' voluto venire? Dissiti che il prete si giaceva ogni notte con meco: e quando fu che tu meco non giacessi? E quante volte il tuo cherico a me mandasti, tante sai, quante tu meco non fosti, ti mandai a dire che il prete meco stato non era. Quale smemorato altri che tu, che alla gelosia tua t'hai lasciato

\footnotetext{
20 The text does not indicate in which part of the church the confession takes place, just that the husband went to her. Though the confessional was not in use before the Reformation, the penitent's privacy was guarded by an appropriate distance from others.
} 
accecare, non avrebbe queste cose intese? E se'ti stato in casa a far la notte la guardia all'uscio e a me credi aver dato a vedere che tu altrove andato sii a cena e a albergo!' (VII.5.55-57; emphasis added)

'I told you I was in love with a priest: but is it not a fact that you, whom I am misguided enough to love, had turned into a priest? I told you he could open any door in the house when he wanted to come and sleep with me: but which of the doors in your own house has ever prevented you from coming to me? And as you know very well, every time you sent that seminarist of yours to me, you had slept elsewhere, and so I sent word that the priest had not been with me. How could anybody, other than a man who had allowed himself to be blinded by his jealousy, have been witless enough not to understand all this? But in your case, what do you do? You spin me some yarn every evening about going to supper and staying the night with friends, then hang about the house keeping an all-night vigil at the front door.' (513)

The words emphasized in the passage indicate that the wife and her husband understand the world through different senses: she creates her world and that of her husband through speech, as the repetition of the word dire suggests, whereas her husband understands reality_falsely — through sight, as implicated in the contrast between accecare and dare a vedere. Because of his allegiance to the visual, the familiarity of his house, his wife, and the abilities of priests have all been distorted for the husband, but the wife's explanation of her confession re-forms order for him in a way that allays his fears and rids him of his jealousy. Therefore, it is not so much the wife who undergoes a transformation in the confessional space as the husband, who has acquired a new understanding of his wife and of language, one that is more socially normative and corrective of his previous vices. Ironically, it is the so-called priest who has been changed by the confession, as opposed to the penitent. ${ }^{21}$ Yet it is the wife's trick that restores social normalcy.

\footnotetext{
21 The conclusion of the story underlines this irony in another way when Fiammetta explains that the jealous husband donned the clothes of jealousy without need, and then cast them off when he, in fact, had reason to be jealous: "e quando la gelosia gli bisognava del tutto se la spogliò, cosí come quando bisogno non gli era se l'aveva vestita” (VII.5.59). His transformation is thus linked to his disguise as a priest.
} 
Separated from the rest of society, and notably out of view of her husband, the lady entertains her neighbour unbeknownst to anyone. In contrast to novella III.3, however, the lady in novella VII.5 does not need to find a separate space to meet her lover; she merely needs to wait for her husband to withdraw from the space that he himself imposed on her. Thus, the secrecy of the false confessional space is mapped onto the lady's bedroom. Through the focus on the closed bedroom, this story cannot help but recall the passage of the Proemio in which the ladies who suffer because of love are confined by their families, in "camere racchiuse" (Proem.10). The wife in VII.5 offers an example of how confinement can be corrective and transformative, for her own room, apart from society, is the only place in which she can entertain her neighbour, where love may in fact flourish, and where she may overcome her "noia" (VII.5.9). As the lady's own narrative helped to transform her husband and her situation, so Fiammetta's novella and Boccaccio's narrative art may transform and even correct the brigata, Boccaccio's lovelorn ladies, and the external audience.

\section{Conclusion}

In all of these stories, the confessional space is potential space: neither good nor bad on its own, it has the possibility to lead to social betterment or else to decline and ruin. It is for this reason that these tales link the sacred and the profane, whether by equating the confessional space with ladies' bedrooms, or by compromising the language of ritual with deceptions and partial truths. Confessions are types of stories, creating a separate space of potential through language. As Boccaccio claims in his final defence of the tales, storytelling has transformative potential: "le quali, chenti che elle si sieno, e nuocere e giovar possono, sí come possono tutte l'altre cose, avendo riguardo allo ascoltatore" (Conc.8; "like all other things in this world, stories, whatever their nature, may be harmful or useful, depending upon the listener," 799). Though the stories that the members of the brigata narrate for each other often demonstrate social or personal change for the characters within a given novella, as is the case in VII.5, in I.1, and to a lesser extent in III.3, the effects of the stories on the lovelorn ladies of the Proemio and on Boccaccio's readers cannot be known.

The social transformation that stories may enact cannot be shown because that would make them part of the storytelling. The limits of storytelling do not go beyond that which the audience may see, for the changes are necessarily beyond 
the terms of the story. Although the brigata's return to Florence at the end of Day Ten marks the end of the brigata's interlude, Boccaccio does not really tell his audience what happens beyond that moment, save for the mention of a search for other pleasures (X.Conc.16). Whereas the stories of confession mocked the characters that were overly dependent on appearances and less attuned to the nuances of language, the message that language may shape reality when followed by action seems to hold for all three of these tales (and even the exceptional II.8). For Boccaccio, words and deeds must go together. The problem with confession as a practice, then, is that it is overly dependent on words. For this reason, it lends itself well to beffe, which are themselves tricks predicated on language more than anything.

In terms of the beffa, words may create a temporary, paradisiacal space, but it must be remembered that the first earthly paradise, the Garden of Eden, was destroyed because of a deception. The felix culpa is predicated on the serpent's trick, ${ }^{22}$ the consequences of which are the fall of man, the loss of innocence, the loss of perfect communion with God, and, in turn, the loss of the language of God. In this way, the liminal episode of confession, of storytelling, and of trickery is a temporary return to a pre-lapsarian space/time, where space is enclosed and protected and time is seemingly unmeasured. In this pre-lapsarian re-creation, unadulterated communication may exist among those who are not deceived and those who are deceived are necessarily expelled. Yet these recoveries of paradise can be of a secular order only; they do not pretend beyond the social world. This is yet another reason why the stories focus on sexuality and the sins of temporal life, because the true paradise is forever lost; it is no longer of this earth. Like the limits of terrestrial space, language also has terms beyond which it fails. But within the confines of the profane, storytelling offers an opportunity for social transformation and potentially for spiritual transformation. In every respect, the liminal spaces of the Decameron stories, ${ }^{23}$ and all of the narrative levels that surround them, are attempts to remake in language and action the Garden of Eden

\footnotetext{
${ }^{22}$ Fontes has noted that the Plague is at the heart of the beffa, for the lack of law is justification for the trickster to deceive (43); see also VI.Conc.9.

${ }^{23}$ In his discussion of the marginality of literature, Mazzotta alludes to Turner's notion of liminality in relation to the neutral space between secular literature and history in which the Decameron was composed, but he is quick to distinguish liminality from marginality ( 49 and 49n7).
} 
and, in the cases of these confession stories, to improve man and society on earth for as long as possible.

University of Notre Dame

\section{Works Cited}

Almansi, Guido. The Writer as Liar. London and Boston: Routledge and K. Paul, 1975.

Andreas Capellanus. Trattato d'amore. Ed. Salvatore Battaglia. Rome: Perella, 1947.

Aquinas, Thomas. Summa theologica. Corpus Thomisticum. Web. 19 July 2017.

Augustine of Hippo. De Doctrina Christiana. Ed. Madeleine Moreau. Paris: Institut d'études augustiniennes, 1997.

Biller, Peter, and Alastair J. Minnis, eds. Handling Sin: Confession in the Middle Ages. Woodbridge, Suffolk, and Rochester, NY: York Medieval Press, 1998.

Boccaccio, Giovanni. Decameron. Ed. Vittore Branca. 1980. Turin: Einaudi, 1992. D’Agostino, Alfonso. La Novella di Cepparello. Revisione Filologica, Introduzione e Note. Milan: LED, 2010.

École française de Rome. L'Aveu: antiquité et moyen-âge: actes de la table ronde organisée par l'École française de Rome avec le concours du CNRS et de l'Université de Trieste, Rome 28-30 mars 1984. Rome: École française de Rome; Paris: Diffusion de Boccard, 1986.

Fontes, Anna. "Le thème de la 'beffa' dans le Décaméron." In Formes et signification de la "beffa" dans la littérature italienne de la Renaissance. Ed. André Rochon. Paris: Université de la Sorbonne Nouvelle, 1972. 11-44.

Getto, Giovanni. Vita di forme e forme di vita nel Decameron. Turin: Petrini, 1972.

Gittes, Tobias Foster. Boccaccio's Naked Muse: Eros, Culture and the Mythopoeic Imagination. Toronto: U of Toronto P, 2008.

Green, R.P.H., ed. and trans. On Christian Doctrine. By Augustine of Hippo. Oxford and New York: Clarendon Press, 1995.

Havely, Nicholas. "Chaucer, Boccaccio, and the Friars." In Chaucer and the Italian Trecento. Ed. Piero Boitani. Cambridge: Cambridge UP, 1983. 249-268. 
Marcus, Millicent. An Allegory of Form: Literary Self-Consciousness in the Decameron. Saratoga, CA: Anma Libri, 1979.

Mazzotta, Giuseppe. The World at Play in Boccaccio's Decameron. Princeton: Princeton UP, 1986.

McNeill, John T., and Helena M. Gamer. Medieval Handbooks of Penance: A Translation of the Principal Libri Poenitentiales and Selections from Related Documents. 1938. New York: Columbia UP, 1990.

McWilliam, G. H., trans. The Decameron. By Giovanni Boccaccio. 2nd ed. London: Penguin Books, 1995.

Ó Cuilleanáin, Cormac. Religion and the Clergy in Boccaccio's Decameron. Rome: Edizioni di Storia e Letteratura, 1984.

Parry, John Jay, ed. and trans. The Art of Courtly Love. By Andreas Capellanus. New York: Columbia UP, 1960.

Payer, Pierre J. Sex and the New Literature of Confession, 1150-1300. Toronto: Pontifical Institute of Mediaeval Studies, 2009.

Turner, Victor. From Ritual to Theatre: The Human Seriousness of Play. New York City: Performing Arts Journal Publications, 1982. . The Forest of Symbols: Aspects of Ndembu Ritual. Ithaca: Cornell UP, 1967.

Usher, Jon. "A 'Ser' Cepparello Constructed from Dante Fragments (Decameron I, 1).” Italianist 23.2 (2003): 181-193. 